\title{
Perancangan Aplikasi Pembelajaran "Fruvenimal" Berbasis HTML5
}

\author{
Teddy Satria ${ }^{1)}$, Adian Fatchur Rochim ${ }^{2)}$, Ike Pertiwi Windasari ${ }^{2)}$ \\ Program Studi Sistem Komputer Fakultas Teknik Universitas Diponegoro \\ Jalan Prof. Sudharto, Tembalang, Semarang, Indonesia \\ satriateddy@gmail.com
}

\begin{abstract}
Golden Age is the time when a child's brain's ability to absorb information is very high. All information supplied will influence the child in later. Technology gives an effect on the progress of children. Computer technology can be a fun learning media and interseted for kid. Therefore, Fruvenimal application is developed as a learning media for introducing fruits, vegetables, and animals from the name, shape, sound, and vitamin via multimedia applications. Fruvenimal application is built using Construct 2. Multimedia aplication development used Multimedia Development Life Cycle (MDLC) which consists of six stages: concept, design, collection of material, manufacture, testing, and distribution / evaluation. For application testing method using the black box Test. Results from this study in the form of a multimedia application named Fruvenimal that can run on HTML5 browser. The application can be a learning media to introduce of fruits, vegetables, and animals for people, especially aged $<8$ so that kid from an early age is able to recognize the diversity of fruits, vegetables, and animals on earth.
\end{abstract}

Keywords : Golden age, multimedia aplication, Mutimedia development life cycle (MDLC), HTML5 browser, Construct 2.

\section{Pendahuluan}

sia anak-anak merupakan masa yang penting.

$\mathrm{U}$ Berdasarkan penelitian tiga pakar pendidikan anak dari Amerika, yakni Dr. Keith Osborn (University of Georgia), Dr. Burton L. White (Preschool Project), dan Prof. Dr. Benyamin S. Bloom (University of Chicago) tingkat intelektualitas otak mengalami perkembangan sebanyak $50 \%$ ketika anak berusia empat tahun, Andrianto dari Zulaehah $^{[3]}$. Oleh karena itu, masa empat tahun pertama ini sering disebut juga sebagai golden age (masa keemasan) karena anak mampu menyerap dengan cepat setiap rangsangan yang masuk. Anak akan mampu menghafal banyak sekali informasi, seperti kata, nada, bunyi-bunyian, gerakkan, dan sebagainya. Hingga usia 8 tahun, anak telah memiiki tingkat intelektualitas otak sekitar $80 \%$. Perkembangan intelektualitas otak ini relatif berhenti dan mencapai kesempurnaannya (100\%) pada usia 18 tahun. Jadi, setelah usia 18 tahun intelektualitas otak tidak lagi mengalami perkembangan.

Pada zaman yang semakin modern senantiasa mempengaruhi pola pikir manusia untuk selalu berperan aktif mengikuti perkembangan tersebut agar mampu bertahan dan mengembangkan pola kehidupan. Era globalisasi dan komputerisasi merupakan wujud nyata dari perkembangan yang terus terjadi ${ }^{[2]}$. Jadi, tidak dipungkiri lagi jika saat ini komputer merupakan kebutuhan sehari-hari untuk membantu manusia menyelesaikan berbagai pekerjaan.

Teknologi di masa kini memberikan pengaruh yang sangat besar terhadap perkembangan anak. Tidak jarang ditemukan anak usia sekolah dasar sudah mahir bermain dan menggunakan komputer. Teknologi komputer bisa menjadi media pembelajaran yang menyenangkan dan disukai anak.

Pendidikan anak pada usia dini tentunya tidak lepas dari suatu media ${ }^{[4]}$. Media itu yang nanti akan menjadi salah satu sarana bagi anak dalam belajar mengenal buah, sayur, dan hewan mulai dari nama, bentuk, suara, dan kandungan vitamin. Sesuai dengan pengaruh perkembangan teknologi informasi, maka akan dikembangkan media pembelajaran buah, sayur, dan hewan (fruvenimal) dengan memanfaatkan teknologi komputer.

Melalui penelitian ini, penulis bermaksud membangun sebuah aplikasi multimedia pembelajaran fruvenimal untuk mengenalkan buah, sayur, dan hewan kepada masyarakat khususnya anak-anak dengan cara yang menyenangkan dan mudah diserap yang dijalankan melalui browser. Untuk itu, dengan dilakukannya penelitian ini, diharapkan dapat menjadi salah satu media pembelajaran fruvenimal yang menyenangkan dan mudah dipahami bagi anak-anak sehingga anak-anak yang dewasa ini kerap menggunakan teknologi komputer tidak hanya menggunakannya untuk bermain permainan umum, melainkan ada unsur edukasi di dalamnya.

Tugas akhir ini bertujuan untuk: mengembangkan sebuah aplikasi multimedia yang dapat menjadi media pengenalan fruvenimal.

Untuk menghindari pembahasan yang meluas, maka dalam tugas akhir ini ditetapkan batasan-batasan masalah sebagai berikut:

a. Yang dibahas pada tugas akhir ini meliputi tahap pengembangan aplikasi menggunakan Construct 2 .

b. Materi dalam aplikasi ini hanya mencakup sejumlah buah, sayuran, serta hewan tertentu.

c. Aplikasi dibuat dengan menggunakan Construct 2.

d. Aplikasi dijalankan pada HTML5 browser (Google Chrome dan Mozilla Firefox).

e. Aplikasi ini hanya bersifat purwarupa dan dapat dikembangkan lebih lanjut.

\section{TINJAUAN PUSTAKA}

\section{A. Multimedia}

Multimedia diambil dari kata multi dan media. Multi berarti banyak dan media berarti media atau perantara. Multimedia adalah gabungan dari beberapa unsur yaitu teks, grafik, suara, video dan animasi yang menghasilkan presentasi yang menakjubkan. Multimedia juga mempunyai komunikasi interaktif yang tinggi. Bagi pengguna komputer multimedia dapat diartikan sebagai informasi komputer yang dapat disajikan melalui audio atau video, teks, grafik dan animasi ${ }^{[9]}$. 
Pengembangan multimedia menurut Luther yang sudah dimodifikasi Sutopo dilakukan berdasarkan 6 tahap, yaitu : concept, design, material collecting, assembly, testing, dan distribution. Seperti pada Gambar $1^{[1]}$.

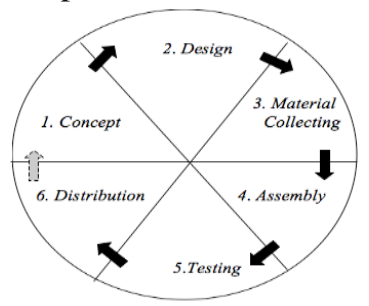

Gambar 1 Tahap pengembangan multimedia.

\section{a. Konsep (Concept)}

Tahap konsep adalah tahap untuk menentukan tujuan dan siapa pengguna program. Selain itu menentukan macam aplikasi (presentasi, interaktif, dll) dan tujuan aplikasi (hiburan, pelatihan, pembelajaran, dll).

b. Perancangan (Design)

Tahap Perancangan (design) adalah tahap membuat spesifikasi mengenai arsitektur program, gaya, tampilan dan kebutuhan material/bahan untuk program.

\section{c. Pengumpulan Materi (Material Collecting)}

Tahap pengumpulan materi adalah tahap dimana pengumpulan bahan yang sesuai dengan kebutuhan dilakukan, seperti image, animasi, audio, foto, audio, dan lain-lain.

d. Pembuatan (Assembly)

Tahap pembuatan adalah tahap dimana semua objek atau bahan multimedia dibuat. Pembuatan aplikasi didasarkan pada tahap design.

\section{e. Pengujian (Testing)}

Tahap pengujian dilakukan setelah selesai tahap pembuatan dan seluruh data telah dimasukkan, dengan menjalankan aplikasi/program dan dilihat apakah ada kesalahan atau tidak.

f. Distribusi (Distribution)

Tahap distribusi adalah Tahapan dimana aplikasi disimpan dalam suatu media penyimpanan.

\section{B. Construct 2}

Construct $2^{[9]}$ adalah software untuk membuat aplikasi game khususnya untuk game 2D berbasis HTML5, yang memungkinkan membuat game tanpa membutuhkan coding. Construct 2 merupakan produk buatan Scirra, perusahaan yang berasal dari London, Inggris.

Pemanggilan fungsi-fungsi di Construct 2 hanya menggunakan pengaturan Events yang telah disediakan. Events merupakan pilihan-pilihan Action dan Kondisi yang akan menjadi nyawa dalam game dan game dapat berjalan sesuai yang kita inginkan.

Berikut adalah beberapa kelebihan Construct 2 :

a. Quick and Easy, Construct 2 memiliki tampilan yang mudah dipahami,bahkan oleh orang awam sekalipun,sehingga membuat games pun jadi lebih mudah dan cepat.

b. Powerfull Event System, sebagai pengganti programing/coding Constuct 2 menyediakan System Event sebagai logika permainan.

c. Flexible Behaviours, yang merupakan fungsi bawaan yang telah disediakan oleh Construct 2,sehingga pengembang tidak perlu membuatnya lagi dari awal. Yang termasuk behaviour disini adalah fisika,pergerakan,platformer,dan lain sebagainya.

d. Instant Preview, dengan menekan tombol run, hasil pemainan sudh bisa dilihat, tanpa menunggu proses compiling yang memakan waktu lama. e. Stunning Visual Effect, Construct 2 sudah menyediakan visual efek untuk membuat permainan lebih menarik.

f. Easy Extensibility, Construct 2 menyediakan SDK untuk membuat plugin tambahan. Pengembang juga bisa membuat visual efek sendiri jika diperlukan.

g. Multiplatform Export, karena permainan yang dihasilkan Construct berbasis HTML5, maka dapat dipublikasikan ke berbagai macam platform, mulai dari Chrome Web Store, Facebook, Kongregate, NewGrounds, Firefox Marketplace, Sencha Arcade. Untuk PC pun bisa, dengan hasil publikasi untuk Windows 8,Linux,Mac. Platform mobile pun juga bisa,seperti iOS,Android,Blackberry.

\section{HTML5 Pada Construct 2}

HTML singkatan dari HyperText Markup Language. HTML adalah aturan standar halaman web yang telah dibuat sejak awal internet. HTML5 merupakan revisi kelima dari HTML5, dan mulai diadopsi pada tahun 2011. HTML5 mengenalkan banyak fitur baru, tetapi hanya sedikit yang diaplikasikan untuk games. Namun HTML5 tetap merupakan diskripsi dari teknologi yang dipakai Construct 2.

HTML5 (Hypertext Markup Language version 5) adalah sebuah bahasa markah yang menstrukturkan isi dari World Wide Web, sebuah teknologi utama pada internet. Standar HTML5 menyempurnakan elemen-elemen lama yang terdapat pada standar sebelumnya, menambahkan elemen-elemen yang lebih semantik dan menambahkan fitur-fitur baru untuk mendukung pembuatan aplikasi web yang lebih kompleks ${ }^{[5]}$.

\section{Audacity}

Audacity adalah perangkat lunak untuk merekam dan menyunting suara ${ }^{[7]}$. Aplikasi ini bersifat open source dan dapat berjalan pada berbagai sistem operasi.

Audacity mampu mengoreksi suara tertentu, atau sekedar menambahkan berbagai efek yang disediakan. Audacity juga digunakan untuk memotong suara, menambahan bahkan mengkonversi ke file lain, diantaranya MP3, Ogg, dan Wave.

Selain itu juga dapat berkreasi dengan suara yang dimiliki sendiri melalui perekam suara.Aplikasi ini sangat ringan dan untuk sekedar konversi file audio cukup handal. Kelebihan dari aplikasi ini adalah fitur dan kestabilan Antar muka yang digunakan juga tidak terlalu banyak dan waktu tunggunya juga tidak terlalu lama.

\section{E. Corel Draw X6}

Corel Draw adalah aplikasi yang melakukan editing pada garis vektor. aplikasi ini dibuat oleh Corel Corporation, sebuah perusahaan software yang didirikan tahun 1985 dan berkantor pusat di Ottawa, Kanada ${ }^{[6]}$. Corel draw memiliki kegunaan untuk mengolah gambar, oleh karena itu banyak digunakan pada pekerjaan dalam bidang publikasi atau percetakan ataupun pekerjaan di bidang lain yang membutuhkan proses visualisasi.

\section{F. Uji Dua Sampel Berpasangan Wilcoxon}

Uji Wilcoxon digunakan untuk menentukan ada tidaknya perbedaan rata-rata dua sampel yang saling berhubungan. Yang dimaksud 'berpasangan' atau 'berhubungan' adalah subyek yang diukur sama, namun diberi dua macam perlakuan ${ }^{[8]}$. Sebagai contoh 30 orang akan diukur nilai sebelum mereka memakai aplikasi dan setelah mereka memakai aplikasi. Dalam hal ini 30 orang tersebut mendapat dua macam perlakuan, yakni perlakuan pertama sebelum memakai aplikasi, kemudian memakai aplikasi, dan bersama-sama juga diukur hasilnya setelah memakai aplikasi. 


\section{PERANCANGAN PENELITIAN}

\section{A. Konsep}

Aplikasi yang dibuat dapat menjadi media pembelajaran yang interaktif untuk mengenalkan keanekaragaman buah, sayur, dan hewan (fruvenimal). Dengan dibuatnya aplikasi ini masyarakat khususnya anak-anak usia $<8$ tahun dapat mengetahui beberapa nama, bentuk, dan informasi mengenai fruvenimal. Dengan mengenal keanekaragaman fruvenimal yang ada di bumi dapat meningkatkan pengetahuan masyarakat khususnya anak-anak akan informasi fruvenimal yang mungkin belum mereka ketahui, sehingga diharapkan dapat meningkatkan pengetahuan tentang informasi dan keanekaragaman fruvenimal.

\section{B. Desain}

Tahap awal dalam desain dibuat sebuah bagan perancangan aplikasi yang berisi bagian-bagian dari aplikasi. Bagan perancangan aplikasi ditunjukkan oleh Gambar 2.

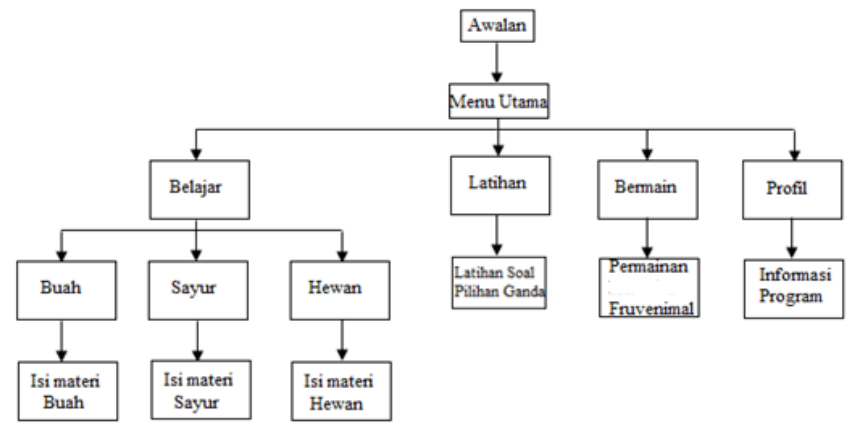

Gambar 2 Bagan perancangan aplikasi

Setelah pembuatan bagan perancangan aplikasi yang dimana dapat menjelaskan bagian - bagian dari aplikasi, maka dilanjutkan dengan pembuatan Diagram Alir yang menjelaskan alur aplikasi yang dibuat.

Aplikasi yang dibuat mempunyai 4 menu utama, yakni menu Belajar, menu Latihan, menu Bermain, menu Profil. Pada halaman menu utama ini ditampilkan semua menu-menu yang ada. Diagram Alir pada menu utama aplikasi ditunjukkan oleh Gambar 3.

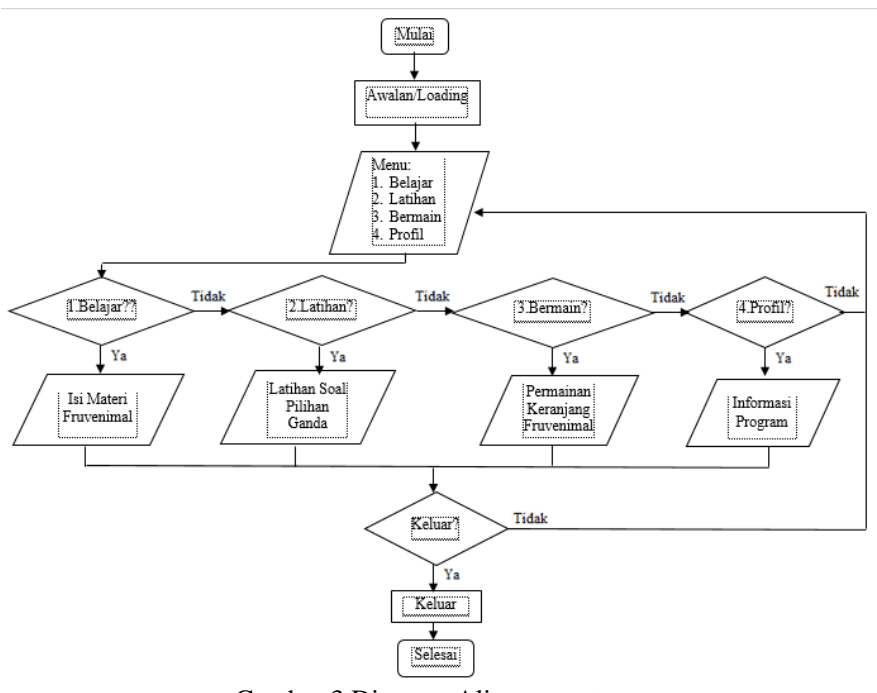

Gambar 3 Diagram Alir menu utama

Menu Belajar berisi materi-materi yang akan di bahas. Materi yang dibahas menu belajar dibagi menjadi 3 yaitu buah, sayur, dan hewan. Diagram alir pada menu belajar ditunjukkan oleh Gambar 4.

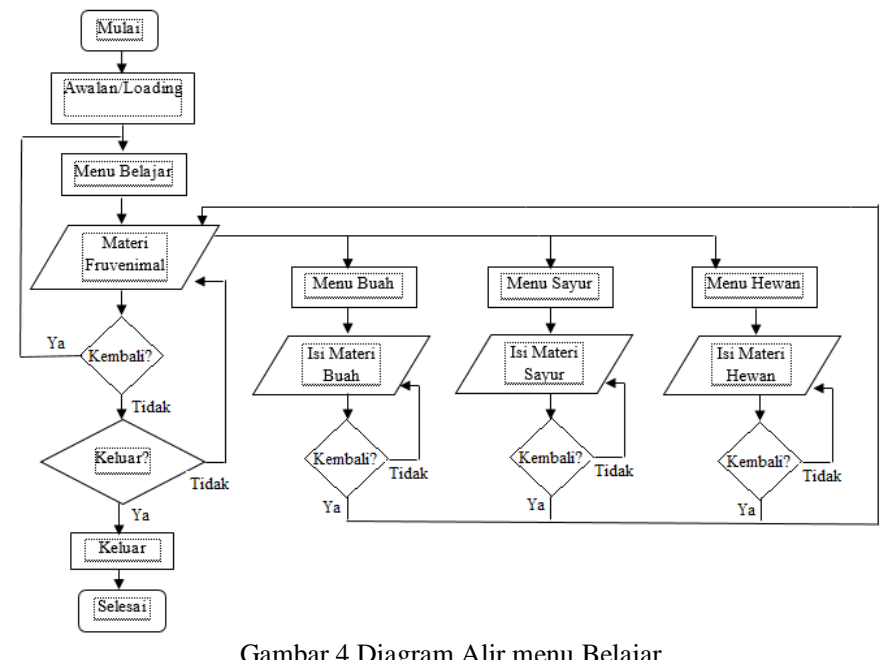

Menu Latihan berisi soal-soal latihan untuk melatih pengetahuan pengguna tentang keanekaragaman fruvenimal. Soal-soal tersebut disajikan dalam bentuk soal pilihan ganda. Diagram Alir pada menu latihan ditunjukkan oleh Gambar 5

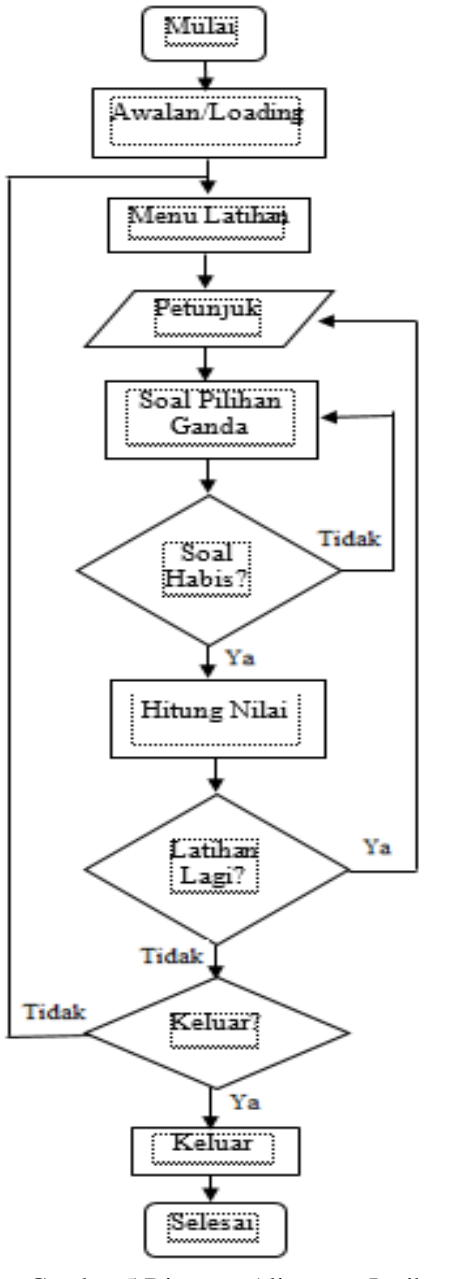

Gambar 5 Diagram Alir menu Latihan

Menu Bermain berisi sebuah permainan untuk melatih pengguna membedakan bentuk buah, sayur, dan hewan. Dalam permainan ini akan ada beberapa objek buah, sayur, dan hewan serta rumah buah, sayur, dan hewan untuk memasukkan objekobjek sesuai dengan rumah. Bila pengguna berhasil memasukkan semua objek ke rumah dengan benar sebelum waktu yang ditentukan habis, maka permainan berhasil dimenangkan. Diagram Alir pada menu bermain ditunjukkan oleh Gambar 6 


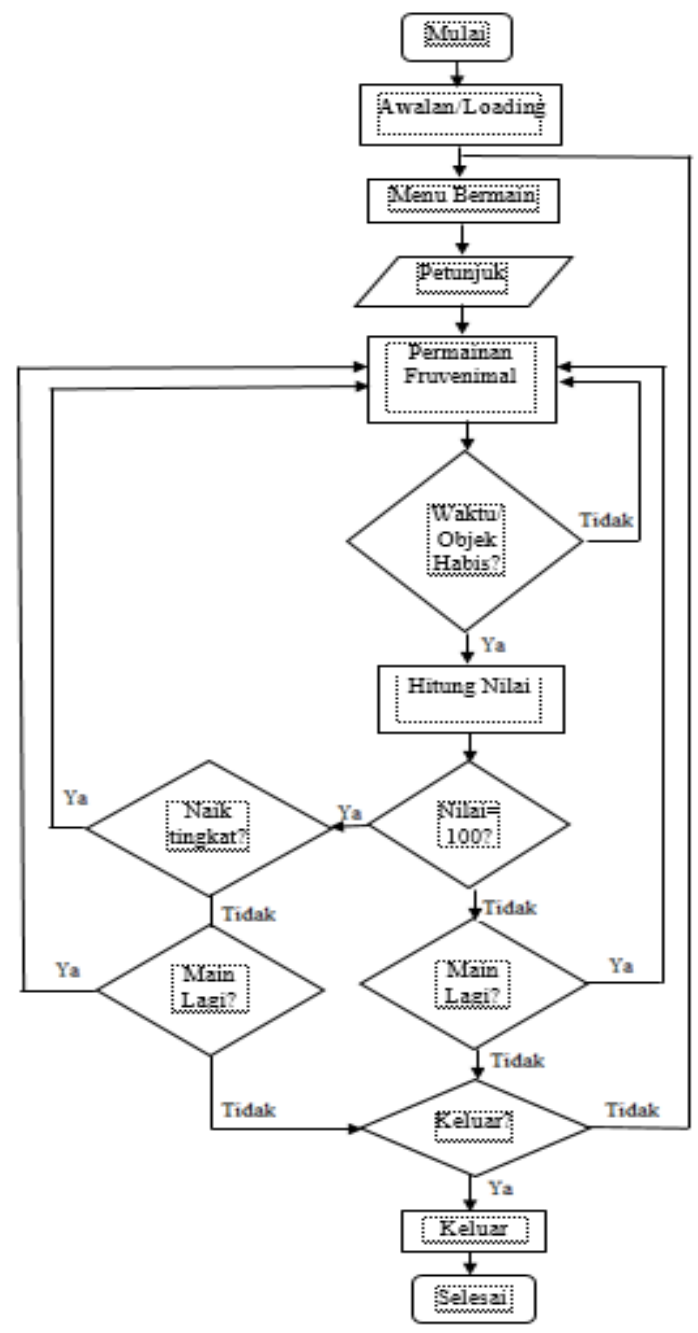

Gambar 6 Diagram Alir menu Bermain

Menu Profil berisi informasi mengenai: pengembang aplikasi, dosen pembimbing pengembang aplikasi, dan sumber. Diagram Alir pada menu profil ditunjukkan oleh Gambar 7

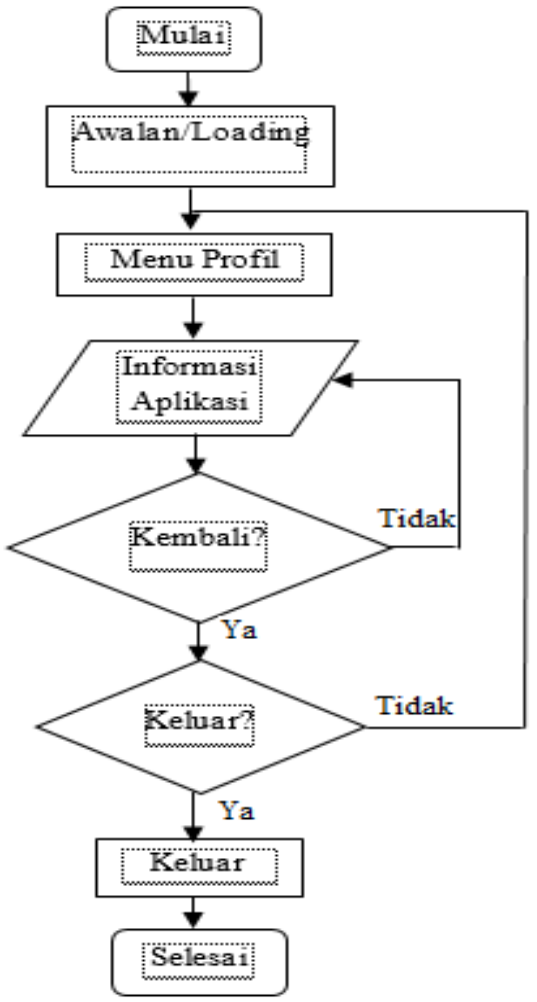

\section{Pengumpulan Materi}

Dalam tahap ini dilakukan pengumpulan materi tentang keanekaragaman fruvenimal yang meliputi: gambar, nama, dan informasi yang akan ditampilkan dalam aplikasi. Keanekaragaman fruvenimal meliputi buah (avokad, durian, jambu biji, jeruk, mangga, melon, pepaya, pisang, semangka), sayur (bawang putih, kacang buncis, cabai, jagung, kentang, kubis, sawi, timun, tomat), dan hewan (ayam, gajah, jerapah, kuda, panda, ular piton, sapi, singa, tikus). Pengumpulan materi juga sebagai bahan pembuatan soal dalam menu Latihan, serta gambar fruvenimal digunakan sebagai pembuatan permainan dalam menu Bermain. Suara didapat dari internet dan diolah menggunakan perangkat lunak Audacity.

\section{ANALISIS HaSIL PENELITIAN DAN PEMBAHASAN}

\section{A. Pengujian Aplikasi}

Pengujian aplikasi Fruvenimal ini dilakukan dengan menggunakan metode black-box. Pengujian ini dilakukan untuk menunjukkan fungsi aplikasi yang dibuat tentang cara operasi dan kegunaannya, apakah keluaran data sesuai dengan yang diharapkan. Pengujian ini dilakukan untuk mengetahui apakah masih terjadi kesalahan fungsi dalam aplikasi atau aplikasi sudah dapat dijalankan dengan benar.

Pengujian aplikasi dibuat berupa tabel - tabel pengujian black-box dari masing-masing menu yang ada dalam aplikasi.

1. Pengujian pada menu utama aplikasi

Tabel pengujian pada menu utama aplikasi ditunjukkan

\begin{tabular}{|c|c|c|c|}
\hline $\begin{array}{c}\text { Nama } \\
\text { Pengujian }\end{array}$ & $\begin{array}{c}\text { Bentuk } \\
\text { Pengujian }\end{array}$ & $\begin{array}{c}\text { Hasil yang } \\
\text { Diharapkan }\end{array}$ & $\begin{array}{c}\text { Hasil } \\
\text { Pengujian }\end{array}$ \\
\hline Loading & $\begin{array}{l}\text { Membuka } \\
\text { aplikasi }\end{array}$ & $\begin{array}{l}\text { Tampilan loading } \\
\text { Construct } 2\end{array}$ & Berhasil \\
\hline $\begin{array}{l}\text { Pengujian } \\
\text { menu } \\
\text { Belajar }\end{array}$ & $\begin{array}{l}\text { Mengklik } \\
\text { tombol } \\
\text { menu } \\
\text { Belajar }\end{array}$ & $\begin{array}{l}\text { Tampil menu- } \\
\text { menu belajar } \\
\text { untuk pemilihan } \\
\text { materi (buah, } \\
\text { sayur, dan hewan) }\end{array}$ & Berhasil \\
\hline $\begin{array}{l}\text { Pengujian } \\
\text { menu } \\
\text { Latihan }\end{array}$ & $\begin{array}{l}\text { Mengklik } \\
\text { tombol } \\
\text { Latihan }\end{array}$ & $\begin{array}{l}\text { Tampil petunjuk } \\
\text { latihan untuk } \\
\text { memulai latihan } \\
\text { soal }\end{array}$ & Berhasil \\
\hline $\begin{array}{l}\text { Pengujian } \\
\text { menu } \\
\text { Bermain }\end{array}$ & $\begin{array}{l}\text { Mengklik } \\
\text { tombol } \\
\text { Bermain }\end{array}$ & $\begin{array}{l}\text { Tampil petunjuk } \\
\text { bermain untuk } \\
\text { memulai } \\
\text { permainan }\end{array}$ & Berhasil \\
\hline $\begin{array}{l}\text { Pengujian } \\
\text { menu Profil }\end{array}$ & $\begin{array}{l}\text { Mengklik } \\
\text { tombol } \\
\text { Profil }\end{array}$ & $\begin{array}{l}\text { Tampil informasi } \\
\text { aplikasi }\end{array}$ & Berhasil \\
\hline
\end{tabular}

Tabel 1 Tabel pengujian menu utama aplikasi 


\section{B. Pengujian Hasil}

Untuk mengetahui secara langsung manfaat aplikasi bagi pengguna, penulis melakukan survey untuk mendapatkan data yang kemudian diolah menggunakan uji peringkat bertanda Wilcoxon dengan SPSS.

Proses pengujian dilakukan dengan cara meminta anakanak sebagai responden untuk menjawab 5 soal pilihan ganda mengenai materi fruvenimal sebelum memainkan aplikasi Fruvenimal, selanjutnya meminta responden memainkan aplikasi Fruvenimal, kemudian memberikan 5 soal lain untuk dijawab, dan menilai apakah ada perubahan pada jumlah jawaban betul di kedua jenis soal atau tidak. Pengujian ini dilakukan dengan tujuan untuk mengetahui pengaruh aplikasi terhadap pengetahuan anak mengenai buah, sayur, dan hewan.

Hasil yang didapat sebelum dan sesudah responden memainkan aplikasi Fruvenimal ditunjukkan oleh Gambar 8.

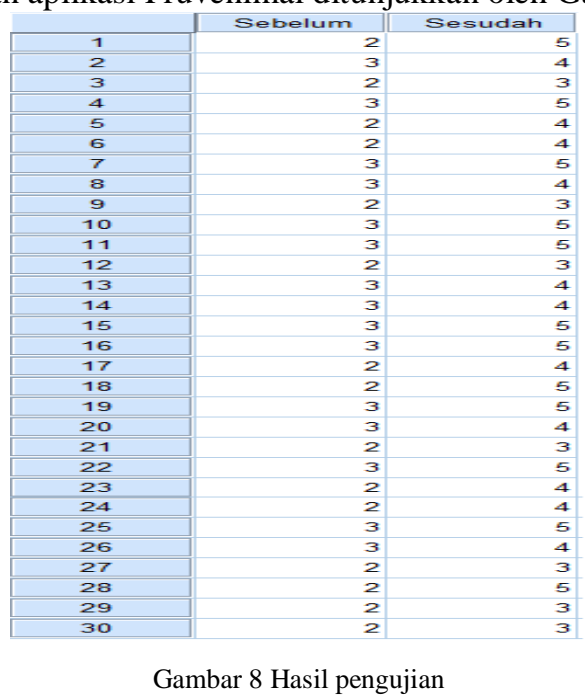

Diagram batang hasil pengujian ditunjukkan oleh Gambar 9.

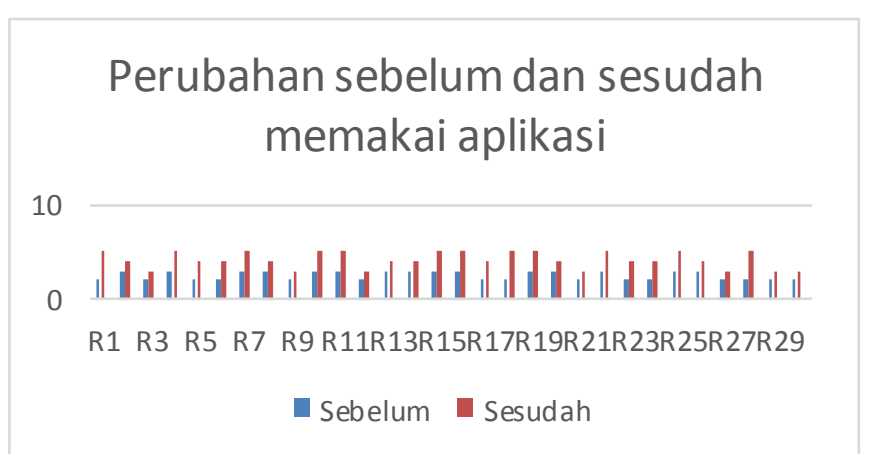

Gambar 9 Diagram batang hasil pengujian

Berdasarkan Gambar 9 dapat dilihat bahwa ada pengaruh aplikasi Fruvenimal terhadap pengetahuan anak.

Dasar pengambilan keputusan dalam uji Wilcoxon:

Jika nilai signifikansi $<0,05$ maka, ada perbedaan sebelum dan sesudah memainkan aplikasi.

Jika nilai signifikansi > 0,05 maka, tidak ada perbedaan sebelum dan sesudah memainkan aplikasi.

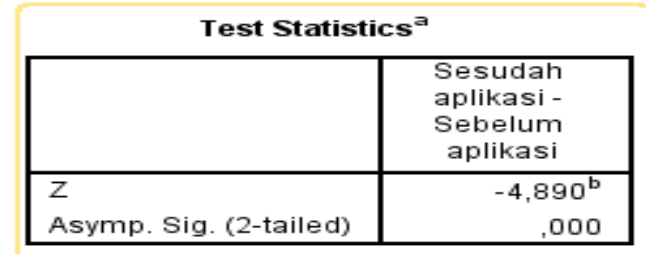

Gambar 10 Output uji Wilcoxon

Interpretasi output dalam uji Wilcoxon dengan SPSS

Gambar 10 merupakan hasil output dari perhitungan uji Wilcoxon dengan SPSS, berdasarkan output di atas diperoleh

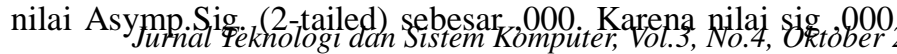

$<$ 0,05 maka dapat disimpulkan bahwa ada perbedaan sebelum dan sesudah menggunakan aplikasi Fruvenimal. Hal ini berarti aplikasi Fruvenimal efektif untuk meningkatkan pengetahuan keanekaragaman buah, sayur, dan hewan pada anak.

\section{Distribusi}

Dalam tahap distribusi ini aplikasi di unggah ke Googledrive, kemudian dibagikan link aplikasi tersebut.

\section{KESIMPULAN DAN SARAN}

\section{A. Kesimpulan}

Dari hasil pengujian dan analisis aplikasi edukatif fruvenimal dapat disimpulkan hal-hal sebagai berikut.

1) Aplikasi di buat menggunakan Construct 2 dan dapat berjalan baik pada HTML5 browser (Google Chrome dan Mozilla Firefox).

2) Berdasarkan hasil pengujian aplikasi menggunakan metode Black-box, seluruh fungsi menu yang ada dalam aplikasi telah berhasil sesuai dengan fungsinya.

3) Berdasarkan hasil pengujian wilcoxon, diperoleh nilai sig sebesar ,000 maka dapat disimpulkan bahwa ada perbedaan sebelum dan sesudah menggunakan aplikasi Fruvenimal. Hal ini berarti aplikasi Fruvenimal efektif untuk meningkatkan pengetahuan keanekaragaman buah, sayur, dan hewan pada anak.

\section{B. Saran}

Saran yang diberikan dalam upaya pengembangan aplikasi yang lebih baik dikemudian hari.

1) Aplikasi Fruvenimal hanya mencakup buah (avokad, durian, jambu biji, jeruk, mangga, melon, pepaya, pisang, semangka), sayur (bawang putih, kacang buncis, cabai, jagung, kentang, kubis, sawi, timun, tomat), dan hewan (ayam, gajah, jerapah, kuda, panda, ular piton, sapi, singa, tikus). Kedepannya mungkin bisa diperluas cakupan aplikasi meliputi buah,sayur, dan hewan yang lain.

2) Dapat ditambahkan efek animasi pada tampilan dan tombol agar aplikasi ini lebih menarik.

\section{DAFTAR PUSTAKA}

[1] Ariesto Hadi, Sutopo. 2003. Multimedia Interaktif dan Flash. Yogyakarta: PT Graha Ilmu.

[2] Fatah, Muhammad Abdul, Pengembangan Media Pembelajaran Interaktif pada Perkuliahan Fisika Dasar 2 Materi Listrik Statis pada Prodi Tadris Fisika Fakultas Ilmu Tarbiyah dan Keguruan Tahun 2012/2013 dengan Macromedia Flash 8, Skripsi, Institut Agama Islam Negeri Walisongo Semarang, 2013.

[3]Hidayati, Zulaehah. 2010. Anak Saya Tidak Nakal, Kok. Yogyakarta: Bentang Pustaka.

[4] Karim, Muhammad Ta'yinul. Perancangan Media Interaktif dan Game untuk Kompetensi Mengelompokkan di Paud. Jurnal-online.um.ac.id/data/artikel/. 10 Mei 2015.

[5]Mavrody, Sergei. (2012). HTML5 \& CSS3: Quick Reference. Chicago : Belisso

[6]Purnomo, Catur Hadi. 2008. 111 Tip \& Trik Menguasai CorelDRAW Graphics Suite X4. Jakarta: Mediakita.

[7] Ramadhan, Arief. 2010. Mengolah Audio dan MP3 dengan Audacity. Jakarta: PT Elex Media Komputindo.

[8]Santoso, Singgih. 2001. Buku Latihan SPSS Statistik Non Parametrik. Jakarta: PT Elex Media Komputindo.

[9] Scirra. Construct 2. http://www.scirra.com. 27 November 2014.

[10] Sulaiman, Septian. Pengertian Multimedia. https://badaiblues.wordpress.com/2013/03/27/pengertianmultimedial 23, November 2014.

JTsiskom - 425 